\title{
The taxonomic identity of the neglected Racomitrium stenocladum (Bryophyta, Grimmiaceae)
}

\section{La identidad taxonómica de Racomitrium stenocladum (Bryophyta, Grimmiaceae)}

\author{
Juan LarRaín ${ }^{1}$, Dietmar Quandt ${ }^{2} \&$ Jesús Muñoz ${ }^{3,4}$ \\ ${ }^{1}$ Departamento de Botánica, Universidad de Concepción, Casilla 160-C, Concepción, Chile. \\ ${ }^{2}$ Nees-Institut für Biodiversität der Pflanzen, Rheinische Friedrich-Wilhelms-Universität, Meckenheimer Allee 170, D-53115 \\ Bonn, Germany. \\ ${ }^{3}$ Real Jardín Botánico (CSIC), Plaza de Murillo 2, 28014, Madrid, Spain. \\ ${ }^{4}$ Universidad Tecnológica Indoamérica, Bolívar 2035, Ambato, Ecuador. \\ juanlarrain@udec.cl
}

\begin{abstract}
RESUMEN
El olvidado nombre Racomitrium stenocladum Dusén es revalidado luego de ser considerado un sinónimo de $R$. orthotrichaceum (Müll. Hal.) Paris (=Bucklandiella orthotrichacea (Müll. Hal.) Bednarek-Ochyra \& Ochyra) por más de 25 años. La especie se distingue de $B$. orthotrichacea por las hojas fuertemente adpresas a los tallos en seco, la forma de la costa en sección transversal y la lámina mayoritariamente de un solo estrato de células. El nombre es lectotipificado y se propone la nueva combinación Bucklandiella stenoclada (Dusén) Larraín. Se presenta además una clave para las especies de Bucklandiella del sur de Sudamérica (al sur de los $30^{\circ} \mathrm{S}$ ).
\end{abstract}

The genus Bucklandiella Roiv. (sensu Ochyra et al. 2003), one of four segregates of Racomitrium Brid., is the most diverse group of the Racomitrioideae in southern South America, with 12 species. Most taxa in the area belonging to Bucklandiella have been moved from Racomitrium by Ochyra et al. (2003), but Racomitrium stenocladum Dusén, treated by Deguchi (1984) as a synonym of B. orthotrichacea (Müll.Hal.) Bednarek-Ochyra \& Ochyra has not. In our opinion it represents a distinct taxon, and is here transferred into Bucklandiella.

Bucklandiella stenoclada (Dusén) Larraín, comb. nov. Basionym: Racomitrium stenocladum Dusén, Ark. Bot. 6(10): 23. 1907.-Protologue: [Chile] Patagonia occidentalis in valle flum. Rio Aysen in declive c. $1,100 \mathrm{~m} \mathrm{~s}$. m. Lectotype (here designated): A12. Rhacomitrium stenocladum Dusén. Patagonia occ. in valle flum. Aysen in saxis. Febr. a. 1897. P. Dusen. (S!, herb. no 138032); isolectotypes: JE!, S! (n ${ }^{\circ}$ 138033). Figs. 25-31.

Additional illustrations. Deguchi 1984 (Fig. 32 A-C, F-H, L, N-Q); Dusén 1907 (Taf. 5, Figs. 6-10, as R. stenocladum); Roivainen 1955 (Fig. 2: e-g).

Discussion. This taxon was described from a collection made by Dusén in February 1897 in the mountains above the Aisén Valley (Aisén Province, southern Chile), at approximately $45^{\circ} 30^{\prime} \mathrm{S}$ and $1100 \mathrm{~m}$ a.s.l. Additional specimens of this taxon were found in $\mathrm{S}$ and JE, also collected by Dusén in the same area, but with a different collection number or no collection number at all. In addition, another specimen was found in S from the coastal mountains of Malleco Province, in Araucanía Region ( $\mathrm{ca} .38^{\circ} \mathrm{S}$ ), labeled as collected by Heikii Roivainen, but with the same collection number as Dusén's type. The plants match in every single character the lectotype, so we think it could represent just a labeling error.

Bucklandiella stenoclada resembles $B$. orthotrichacea in the shape and size of its leaves; leaf apex that ends in a very short hyaline mucro or is muticous; short (mostly quadrate) median and upper laminal cells; presence of a well-defined basal marginal band of differentiated cells; and strongly pseudopapillose lamina. However, B. orthotrichacea has costae with (3-)4(-5) cell layers and up to 6 ventral cells in the proximal part of leaves, rounded dorsally, and it is 3-4-stratose in the upper half of the leaves (Figs. 1-24). In contrast, B. stenoclada has thinner costae, mostly 23 -stratose and up to 4 ventral cells in the proximal part, reniform to flattened, and it is bistratose distally (although with a few 3-stratose spots). Many authors think that the shape of the costa is constant in the different species of this genus, and maybe the best character for delimiting species in Bucklandiella (e.g., Frisvoll 1988).

Bucklandiella stenoclada differs from $B$. orthotrichacea in having appressed leaves; julaceous stems when dry; different costa shape; and coarser and more pronounced pseudopapillae in its leaves. Additionally, B. orthotrichacea often has bistratose distal margins for several rows, while 
B. stenoclada has mostly unistratose margins, or when bistratose, only in one or two cell rows (Figs. 25-31). This last character however, is quite variable, at least in the South American species of Bucklandiella and, as already noted by Deguchi (1984), there are some Fuegian specimens of $B$. orthotrichacea that have almost completely unistratose margins, e.g., Roivainen 2647 (H!, type of R. stenocladoides Roiv., Figs. 18-24) and Roivainen 2680 (S!) both from Monte Buckland. These mostly unistratose-bordered specimens, however, represent a rare phenotype of $B$. orthotrichacea, found on less than $5 \%$ of the total collections examined.
Racomitrium stenocladoides $(=R$. orthotrichaceum fide Deguchi 1984) presents great difficulties in recognizing $B$. stenoclada at the species level because it represents intermediate plants between $B$. orthotrichacea and $B$. stenoclada (see Deguchi 1984). However, the type of $R$. stenocladoides has 3-4 stratose costae proximally, and it is perfectly rounded dorsally in cross section, even in the upper part of the leaves, (Figs. 18-24). Unfortunately, all collections of $R$. stenocladoides are sterile, and their sporophytes could not be evaluated.
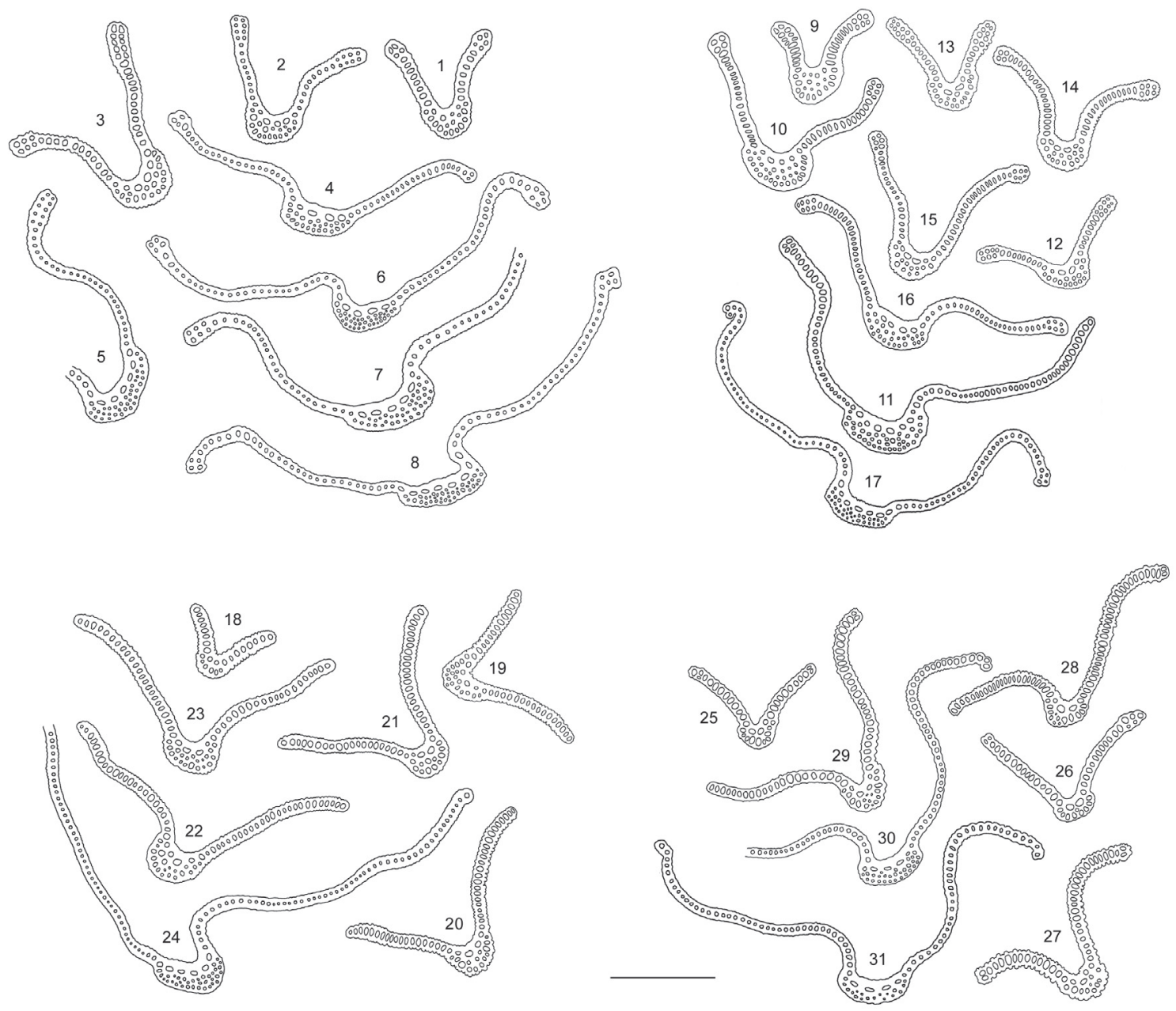

Plate 1. Leaf cross sections from apex to base of Bucklandiella orthotrichacea (1-24) and B. stenoclada (25-31). Figs. 1-8, type of Grimmia orthotrichacea, from Kerguelen Is. (1, 2, 5 and 7 from lectoype at HBG; 3, 4, 6 and 8 from isolectotype at H). Figs. 9-17, Chilean specimens of B. orthotrichacea: Figs. 9-11 from Roivainen 722, Estancia Vicuña, Fuegia (S); Figs. 12-17 from Pizarro E16, Cerro Derrumbe, Llanquihue (PUCV). Figs. 18-24, holotype of Racomitrium stenocladoides, Roivainen, Mt. Buckland, Fuegia (H). Figs. 25-31, lectotype of Racomitrium stenocladum, Dusén A12, Aisén (S). Scale bar: $125 \mu \mathrm{m}$.

LÁmina 1. Secciones transversales de hojas desde el ápice a la base de Bucklandiella orthotrichacea (1-24) y B. stenoclada (25-31). Figs. 1-8, tipo de Grimmia orthotrichacea, de isla Kerguelen (1, 2, 5 y 7 del lectotipo en HBG; 3, 4, 6 y 8 del isolectotipo en H). Figs. 9-17, especímenes chilenos de B. orthotrichacea: Figs. 9-11 de Roivainen 722, Estancia Vicuña, Tierra del Fuego (S); Figs. 12-17 de Pizarro E16, Cerro Derrumbe, Llanquihue (PUCV). Figs. 18-24, holotipo de Racomitrium stenocladoides, Roivainen, Monte Buckland, Tierra del Fuego (H). Figs. 25-31, lectotipo de Racomitrium stenocladum, Dusén A12, Aisén (S). Escala: $125 \mu \mathrm{m}$. 
For the correct use of this key, cross sections of leaves must be done in the basal, medial, and upper part of leaves (always more than one leaf, hopefully several to see variation) taken from the upper part of healthy stems.

1. Leaves conspicuously plicate throughout.

B. ptychophylla (Mitt.) Bednarek-Ochyra \& Ochyra

1 '. Leaves not or slightly plicate.

2. Leaf lamina bistratose for most of its extension in most leaves, especially above midleaf; costa thick, 3-6-stratose at midleaf................3

2'. Leaf lamina unistratose, or bistratose only in 1-3(-6) marginal rows; costa thinner, 2-4-stratose at midleaf.......................................4

3. Costa nearly $1 / 4$ of the leaf base width; leaf margins not clearly thickened ....

B. bartramii (Roiv.) Roiv.

3'. Costa less than $1 / 6$ of the leaf base in width; leaf margins thickened into 2-4(-5)-stratose bands several cell rows wide.

B. lamprocarpa (Müll. Hal.) Bednarek-Ochyra \& Ochyra

4. At least some leaves ending in long hyaline hairpoints or concolorous hair-like subula.

4'. Leaves never ending in a long hyaline hairpoint or a concolorous hair-like subula, at the most ending in a short, thorn-like hyaline point or mucro...

5. Plants robust; costa wide and flat dorsally, often deeply canaliculated in a wide and deep groove in the proximal portion, with 6-12 enlarged ventral cells at midleaf; plants often hoary due to very long hyaline hairpoints.............B. striatipila (Cardot) Bednarek-Ochyra \& Ochyra

5'. Plants small; costa narrow and dorsally convex, not conspicuously canaliculated in a deep groove in the proximal portion, with at most 3 ventral cells at midleaf; plants not hoary, from brown-green to yellow, or reddish (when reddish some leaves can have hairpoint and others just a concolorous hair-like subula).................................................... heterostichoides (Cardot) Bednarek-Ochyra \& Ochyra

6. Section of costa asymmetric (better seen in cross-sections at lower and middle part of leaves); leaves unistratose throughout................7

6'. Section of costa symmetric throughout; leaves often with bistratose borders in apical part................................................................

7. Plants often black or olive green; leaves without basal marginal border of pellucid and straight-walled cells; apex often ended in a stout hyaline mucro; costa percurrent; cells with notorious transverse thickenings when observing the leaf surface ............................................................................................... B. rupestris (Hook. f. \& Wilson) Bednarek-Ochyra \& Ochyra

7'. Plants light to dark green, never black; leaves often with a basal marginal border of 10-15 pellucid and straightwalled cells; apex never ended in a hyaline mucro, often obtuse; costa subpercurrent; leaf surface without transverse thickenings............................................................................................ p. pachydictyon (Cardot) Bednarek-Ochyra \& Ochyra

8. Costa semicircular in cross section in medial and apical part of leaves, 3-4-stratose at midleaf..

8'. Costa reniform to flattened in cross section in medial and apical part of leaves, 2-3-stratose at midleaf ...........................................10

9. Leaves pseudopapillose (papillosity due to longitudinal cuticular thickenings), specially at the distal part; basal marginal row of hyaline and smooth-walled cells usually present and double; hyaline point never present, at most a few hyaline cells in the leaf apex; peristome teeth undivided

B. orthotrichacea

9'. Leaves smooth throughout; basal marginal row of hyaline and smooth-walled cells not present, or formed by a single row of at most five hyaline and smooth walled cells; hyaline point often present, short and denticulate; peristome teeth often divided

.B. sudetica (Funck) Bednarek-Ochyra \& Ochyra

10. Plants usually robust, with erect shoots; leaves more than $2.5 \mathrm{~mm}$ long, ending in a stout hyaline mucro with uneven borders at the apex; margins usually bistratose in one to several cell rows (seldom monostratose throughout)

B. didyma (Mont.) Bednarek-Ochyra \& Ochyra

10'. Plants medium-sized or small, with prostrated, creeping or reduced stems; leaves less than $2.5 \mathrm{~mm}$ long, muticous or ending in a very short hyaline mucro with entire borders at apex; margins mostly unistratose with few bistratose spots...........................................11

11. Stems at most $15 \mathrm{~mm}$ long, forming dense cushions of intermingled dichotomous erect branches on rocks, not julaceous when dry; costa in cross section with up to 6 enlarged ventral cells in the proximal part; differentiated basal marginal border absent or slightly developed; leaf cross section smooth or cells slightly bulging; leaf apex cucullate, with no trace of hyaline mucro...............B. sp. nov.

11'. Stems longer than $20 \mathrm{~mm}$, with prostrated or creeping stems, julaceous when dry; costa in cross section with up to 4 enlarged ventral cells in the proximal part; differentiated basal marginal border present, consisting in one or two rows of hyaline and straight-walled, mostly quadrate cells; leaf cross section strongly pseudopapillose; leaf apex acute, muticous or ending in a short hyaline mucro ..........

B. stenoclada

Additional specimens examined. CHILE. Región de la Araucanía, Provincia de Malleco, in montibus "Cordillera de la Costa", supra Angol urbem, Roivainen A12 (S). Región de Aisén, Provincia de Aisén, in valle fluminis Aysén, Dusén A12 (S, JE - type of Racomitrium stenocladum), Dusén 599 (S), Dusén A62 (S), Dusén s.n. (S 138011).

\section{ACKNOWLEDGEMENTS}

We acknowledge the curators of the herbaria mentioned in the text for the loan of specimens. This contribution was funded by a CONICYT doctoral scholarship given to JL, and the grant CGL2009-09530-BOS of the Ministry of Science and Technology of Spain to JM. 


\section{REFERENCES}

Deguchi, H. 1984. Studies on Some Patagonian Species of Grimmiaceae (Musci, Bryophyta). In: H. Inoue (ed.), Studies on cryptogams in southern Chile, pp. 17-72. Kenseisha, Ltd., Tokio.

DusÉn, P. [1906] 1907. Beiträge zur Bryologie der Magellansländer von Westpatagonien und Südchile V. Arkiv för Botanik utgivet av K. Svenska Vetenskaps-Akademien 6(10): 1-32, Tafl. 1-6.
Frisvoll, A.A. 1988. A taxonomic revision of the Racomitrium heterostichum group (Bryophyta, Grimmiales) in N. and C. America, N. Africa, Europe and Asia. Gunneria 59: 1-289.

Ochyra, R., J. Żarnowiec \& H. Bednarek-Ochyra. 2003. Census catalogue of Polish mosses. Biodiversity of Poland 3: 1372.

Roivainen, H. 1955. Contribution to the Fuegian species of the genus Racomitrium Bridel. Archivum Societatis Zoologicae Botanicae Fennicae 'Vanamo' 9: 85-98.

Recibido: 16.03.11

Aceptado: 19.05.11 